\title{
Evaluation of deletion of nuclease genes cluster in L. major
}

\author{
Noushin Davoudi ${ }^{1 *}$, Maryam Hejazi ${ }^{1}$, Zahra Khodayari ${ }^{1}$, Robert W McMaster ${ }^{2}$ \\ From Institut Pasteur International Network Annual Scientific Meeting \\ Hong Kong. 22-23 November 2010
}

The nuclease is a surface enzyme unique to trypanosomatid parasites. These organisms lack the pathway for de novo purine biosynthesis and thus are entirely dependent upon their hosts to supply this nutrient for their survival, growth, and multiplication. There is a cluster on chromosome 30 which carries 2 copy of nuclease genes and 5 identical nuclease like proteins in $L$. major which are in cis form with 700-800 bp intergenic regions which have more than $80 \%$ homology. These data shows that this enzyme might play an important role in facilitating the survival, growth, and development of this important human pathogen. In previous studies, have been shown that $L$. major $3^{\prime} \mathrm{NT} / \mathrm{NU}$ which is expressed specifically in promastigotes is not the key molecules involved in host purine salvaging pathway and thus in better understanding parasite strategies adopted to survive in sandflies. Therefore, only deletion of nuclease genes followed by sandfly infections experiments will allow determining its precise role in purine salvaging and sandfly infection and specificity. We have developed nuclease cluster heterozygote and homozygote knockout mutants, with homologous recombination technique, to evaluate deletion effects on survival of parasite and infection.

\section{Author details}

'Research Center of Biotechnology, Department of Biotechnology, Pasteur Institute of Iran, Tehran, 13169, Iran. ${ }^{2}$ Department of Medical Genetics, University of British Columbia, Vancouver Hospital, Vancouver, British Columbia, Canada V6H $3 Z 6$.

Published: 10 January 2011

\footnotetext{
* Correspondence: davoudi@pasteur.ac.ir

'Research Center of Biotechnology, Department of Biotechnology, Pasteur Institute of Iran, Tehran, 13169, Iran

Full list of author information is available at the end of the article
}

doi:10.1186/1753-6561-5-S1-P39

Cite this article as: Davoudi et al.: Evaluation of deletion of nuclease genes cluster in L. major. BMC Proceedings 2011 5(Suppl 1):P39.
Submit your next manuscript to BioMed Central and take full advantage of:

- Convenient online submission

- Thorough peer review

- No space constraints or color figure charges

- Immediate publication on acceptance

- Inclusion in PubMed, CAS, Scopus and Google Scholar

- Research which is freely available for redistribution
() Biomed Central 